\title{
The roles of habitat features, disturbance, and distance from putative source populations in structuring alien plant invasions at the urban/wildland interface on the Cape Peninsula, South Africa
}

\author{
Karen P. Alston ${ }^{a}$, David M. Richardson ${ }^{b, *}$ \\ ${ }^{a}$ Percy FitzPatrick Institute of African Ornithology, University of Cape Town, Private Bag, Rondebosch 7701, South Africa \\ ${ }^{\mathrm{b}}$ Centre for Invasion Biology, Department of Botany and Zoology, Stellenbosch University, Private Bag X1, Matieland 7602, South Africa
}

\section{A R T I C L E I N F O}

Article history:

Received 15 August 2005

Received in revised form

15 March 2006

Accepted 31 March 2006

Available online 23 May 2006

\section{Keywords:}

Alien plant invasion

Biological invasions

Disturbance

Invasive alien plants

Non-native species

Suburban gardens

\begin{abstract}
A B S T R A C T
Natural areas are becoming increasingly fragmented and embedded in an urban matrix. Natural and semi-natural areas at the urban/wildland interface are threatened by a variety of 'edge effects', and are especially vulnerable to invasion by introduced plants, with suburban gardens acting as significant sources of alien propagules. Urban/wildland interfaces also provide access for humans, leading to various types of disturbance. Alien plant invasions are one of the biggest threats facing remaining natural areas on the Cape Peninsula, South Africa. The area provides an ideal opportunity to study the dynamics of invasions at the urban/wildland interface, since the largest natural area, the Table Mountain National Park (TMNP), is surrounded by the city of Cape Town. We explored invasion patterns in Newlands Forest (a small section of the TMNP) and detailed the roles of habitat features and distance from putative source populations in three main habitat types: natural Afromontane forest, riverine woodland habitats, and plantations of exotic pines (Pinus radiata and P. pinaster). We also examined the role of disturbance in driving invasions in two of these habitat types (Afromontane forest and pine plantations). We hypothesized that alien richness and alien stem density would decrease with distance from the urban/wildland interface, and that alien richness and alien stem density would increase with increasing levels of human disturbance.

Distance from putative source populations and levels of anthropogenic disturbance influenced alien richness in Newlands Forest but not alien stem density. Alien richness decreased significantly with distance from presumed sources in the pine habitat, and increased significantly with disturbance in the forest habitat. Percentage overstorey cover and soil $\mathrm{pH}$ were important environmental variables associated with alien plant species. A socio-economic approach is discussed as being the most effective approach to the management and prevention of alien plant species in Newlands Forest.
\end{abstract}

(c) 2006 Elsevier Ltd. All rights reserved.

* Corresponding author: Fax: +27 218082995.

E-mail address: rich@sun.ac.za (D.M. Richardson).

0006-3207/\$ - see front matter @ 2006 Elsevier Ltd. All rights reserved.

doi:10.1016/j.biocon.2006.03.023 


\section{Introduction}

As urbanisation increases, natural areas are becoming increasingly fragmented and surrounded by human settlements (Saunders et al., 1991; Hobbs and Yates, 2003), creating ever more urban/wildland interfaces. These interfaces are subject to edge effects generally associated with fragmentation (Saunders et al., 1991) and to a range of pressures resulting from their proximity to urban environments. Types of edge effects include changed environmental conditions, especially microclimates in fragmented forests (Fraver, 1994; Murcia, 1995; Hobbs and Yates, 2003), increased abundance of alien species (Brothers and Spingarn, 1992; Hobbs and Yates, 2003), and altered disturbance regimes (Hobbs and Yates, 2003).

Natural environments at the urban/wildland interface experience increased levels of air and water pollution (Struglia and Winter, 2002) and erosion or sedimentation through augmented water run-off from the hard surfaces characteristic of urban areas (Gill and Williams, 1996). Urban/wildland interfaces are also vulnerable to invasion, partly because suburban gardens are important sources of alien plants (Sullivan et al., 2001; Raloff, 2003). Also, garden refuse is frequently dumped into surrounding ecosystems, and gardens are often extended illegally (Gill and Williams, 1996). Alien plant establishment and soil nutrient enrichment have been identified as two important influences of urban areas at urban/wildland interfaces (Gill and Williams, 1996).

Horticulture is an important pathway for the introduction of alien plants (Reichard and White, 2001; Richardson et al., 2003), and horticultural plants are among the most important invaders in many parts of the world (Reichard and Hamilton, 1997; Baskin, 2002). Many ornamental plants have 'showy' fruit displays, attracting generalist seed dispersers; such species, grown by gardeners at numerous foci near the urban/ wildland interface, are well placed to spread into natural areas.

Until about 1910, most plant introductions to South Africa entered the country via the southwestern Cape, particularly the Cape Peninsula which has the country's oldest port (Wells et al., 1986). The Cape Peninsula is situated within the Cape Floristic Region (CFR), an area of exceptional biodiversity and endemism (Trinder-Smith et al., 1996; Richardson et al., 1998). Three main factors threaten the region's biodiversity: agriculture, urbanization, and alien plant invasions (Richardson et al., 1996; Rouget et al., 2003; Latimer et al., 2004). In 1994, dense stands of woody alien species covered about $11 \%$ of the remaining natural vegetation of the Peninsula and another 33\% was lightly invaded (Richardson et al., 1996). If left unmanaged these alien plants could potentially spread to cover over $89 \%$ of the Cape Peninsula (Higgins et al., 1999). Preventing further spread of alien plants is a clear priority for conservation managers (Richardson et al., 1998).

The problem posed by alien plant invasions on the Cape Peninsula is made worse by the fact that the area is surrounded by one of South Africa's fastest growing metropolises, Cape Town (Cowling et al., 1996). Natural and semi-natural areas on the Cape Peninsula are increasingly subjected to the edge effects posed by human settlements. Settlements also contain many open areas with high levels of disturbance and solar radiation conditions, such as roadsides, which then promote establishment through transport via vehicles. Distance from human habitation is also an important factor in alien plant invasion (Sullivan et al., 2001).

Disturbance is an important determinant of invasibility (Hobbs and Huenneke, 1992; Davis, 2003). Invasion may be facilitated through disturbances associated with roads and streams, both of which create disturbance channels and dispersal corridors, removing competition and creating open areas or dispersing propagules (Parendes and Jones, 2000). The urban/wildland interface facilitates access and opportunities for humans to disturb natural habitats, for example through trail construction and detrimental vegetation management (Bolger et al., 1997); e.g. vegetation trampling and refuse dumping (Sullivan et al., 2001), plant collecting and illegal bark harvesting (Geldenhuys, 2000), and erosion and soil damage (Rose and Fairweather, 1997).

Invasion is also influenced by propagule pressure: the greater the number of propagules, the greater the chance of establishment, persistence, naturalization and invasion (Lonsdale, 1999; Rouget and Richardson, 2003). Initial stages of invasion are usually constrained by the availability of propagules and high propagule pressure can, in some instances, be a better predictor of alien plant cover than any suite of environmental factors (McKinney, 2002; Rouget and Richardson, 2003; Foxcroft et al., 2004).

Many of the factors discussed above interact. For example, disturbance creates edges that threaten plant communities with increased solar radiation, higher temperatures, altered soil conditions, and may result in plant mortality through regeneration failure (Fraver, 1994; Hobbs and Yates, 2003). Alien plants may in turn exploit these edges, invading from sources with a high availability of propagules (Parendes and Jones, 2000).

We explored invasion patterns in a section of the Table Mountain National Park (until 2003 the Cape Peninsula National Park) dominated by Afromontane forest that adjoins suburban gardens. We provide an inventory of invasive alien plants and explore the roles of habitat features, dispersal distance and disturbance in structuring invasion patterns in the three main habitat types in the area. We tested two main hypotheses: (1) alien richness and alien stem density decreases with increasing distance from the suburban/wildland interface; (2) alien richness and alien stem density increases with increasing levels of disturbance. We also explore the implications of the results for long-term management of Newlands Forest.

\section{Methods}

\subsection{Study area}

Our study area was Newlands Forest $\left(33^{\circ} 58^{\prime} \mathrm{S} 18^{\circ} 26^{\prime} \mathrm{E}\right)$, located on the lower eastern slopes of Table Mountain, and forming part of the Table Mountain National Park (Fig. 1). Soils in the area are generally deep $(300-1200 \mathrm{~mm})$ with a high clay 


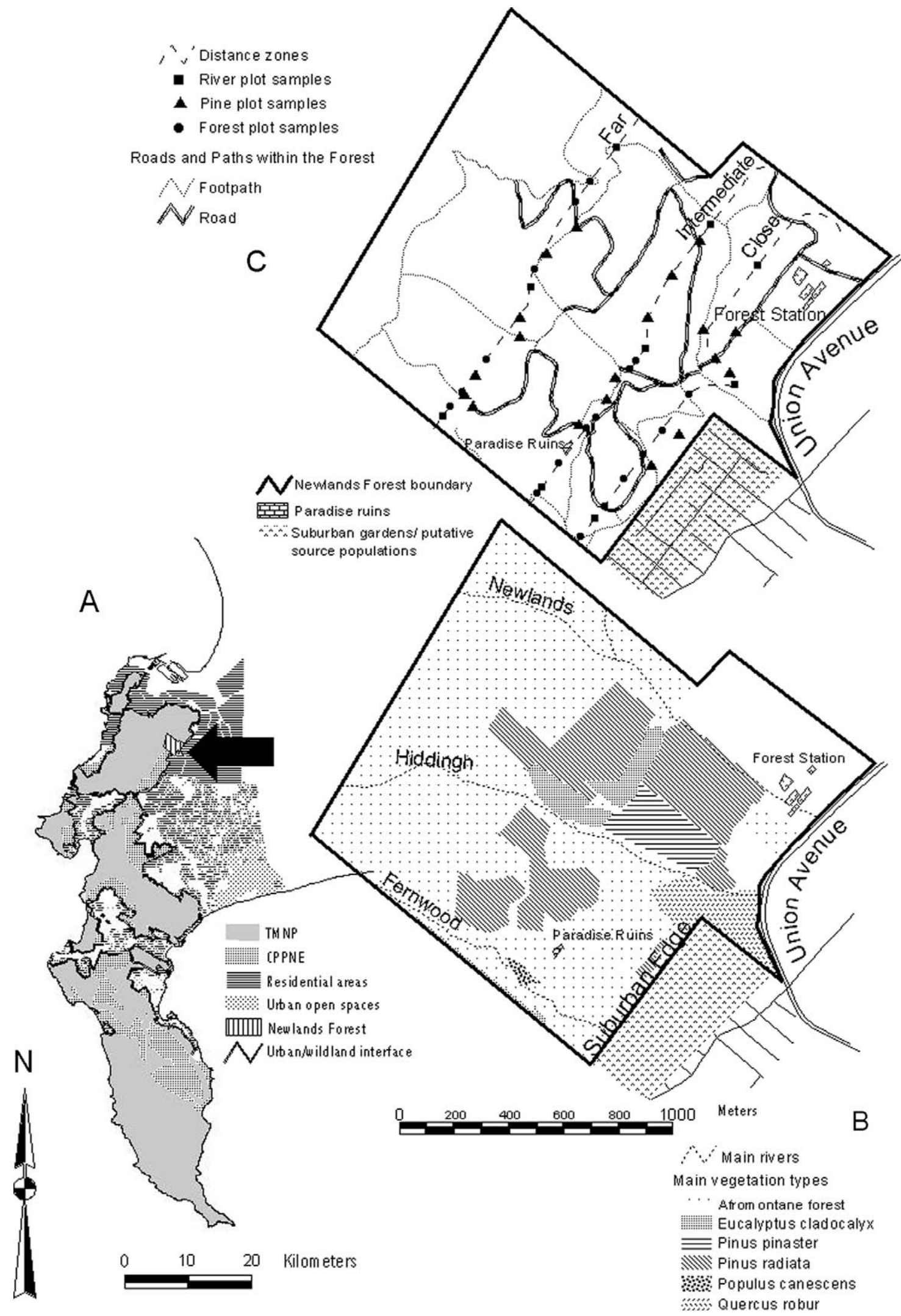

Fig. 1 - Map of the Cape Peninsula, South Africa, showing Newlands Forest in relation to the Table Mountain National Park (TMNP), Cape Peninsula Protected Natural Environment (CPPNE) and surrounding residential areas (A), and detailed maps of Newlands Forest showing the three main rivers, main vegetation types, ruins of the Paradise homestead, suburban edge, Forest Station, Union Avenue (B), and location of sampling plots, distance zones from the suburban edge, and main roads and footpaths (C). 
content (15-35\%) (Eikelenboom and van der Voort, 2002), relatively nutrient-rich, and slightly acidic (Cowling et al., 1996). The dominant natural vegetation types in the area are forest and fynbos (Cowling et al., 1996). Forests occupy less than 3\% of the Peninsula (the largest remnant is at Newlands; McDowell, 1994) and are threatened by problems associated with both the developed (urbanization, industry, pollution, alien organisms) and developing (bark and plant harvesting) sectors of the human population of the region (Geldenhuys et al., 1986; Cowling et al., 1996). The main alien plant species threatening the forest vegetation type on the Peninsula are, in order of invasion importance: Acacia cyclops, Pinus radiata, Eucalyptus spp., P. pinaster, and E. lehmannii (Richardson et al., 1996).

Newlands Forest (250 ha) comprises a mosaic of relict native Afromontane forest (111.7 ha), Pinus pinaster and P. radiata plantations (27.1 ha), Eucalyptus cladocalyx plantations (53.3 ha), and fynbos. There are also stands of Populus canescens and Quercus robur (McDowell, 1994). Structurally, Newlands Forest is a tall forest consisting of several layers and an uneven overstorey surface producing varying light conditions that favour growth of a variety of plants in different microhabitats. Small gaps created by windfalls are the main type of natural disturbance (Geldenhuys, 2000). The region has a long history of human activity and resultant disturbance from timber extraction and silvicultural practices, high-density adjacent urban development, and considerable recreational usage.

The three main rivers occurring in Newlands Forest (Fernwood-, Hiddingh- and Newlands Rivers) were chosen along with representative stands of native Afromontane forest and pine plantations to determine how disturbance, habitat features or distance from putative source populations have influenced alien plant invasions. These habitats contain sufficiently large patches, which are widely distributed throughout the forest, to allow extensive sampling.

Suburban gardens located adjacent to the Table Mountain National Park, the Forest Station (of the City of Cape Town Municipality) situated at the main entrance of the Forest, and roadside plantings along Union Avenue (Fig. 1) are considered as the most important putative sources of alien plants. The Forest Station has a variety of horticultural species as a result of a policy adopted by the City of Cape Town in 1947 to transform the "sombre pine forests" into "attractive mixed forests". The policy also promoted "ornamental and scenic tree planting" to enhance the area (Eikelenboom and van der Voort, 2002).

\subsection{Field sampling}

Data were collected during November 2003 from 59 plots distributed over the study area (Fig. 1), of which 26 were in pine plantations, 24 in Afromontane forest, and nine in riverine woodlands. Sampling was stratified and random; plots of high, medium and low levels of human disturbance were selected in native Afromontane forest and pine plantation habitats at $100 \mathrm{~m}, 300 \mathrm{~m}$ and $700 \mathrm{~m}$ from the suburban edge, which was considered as the boundary between permanently human-modified urban areas (i.e. presumed source areas) and adjacent semi-natural vegetation. The farthest distance chosen was $700 \mathrm{~m}$ since it was the outermost zone that incorporated all three habitat types. Distance from putative sources of alien plants was determined using Spatial Analyst in $\mathrm{ArcView}^{\mathrm{TM}}$, a geographic information system, and was verified on the ground using a hand-held global positioning system and tape measure.

Levels of disturbance were determined by frequency of path usage from surveys conducted by TMNP staff on the intended routes of the recreational users of Newlands Forest (C. Potgieter, pers. commun., McLachlan and Moll, 1977). Roads and frequently used paths were considered as highly disturbed areas, moderately used paths were considered areas of medium disturbance while patches positioned far from paths were deemed areas of low disturbance. Examination of the influence of disturbance on alien plant invasion was limited to the two terrestrial habitats since rivers are moist habitats subject to continuous natural disturbance, unlike the intermittent disturbances of forest and pine habitats.

Plot size measured $50 \times 4 \mathrm{~m}\left(200 \mathrm{~m}^{2}\right)$ in the two terrestrial habitat types and $25 \times 4 \mathrm{~m}\left(100 \mathrm{~m}^{2}\right)$ in riverine habitats to avoid extending into terrestrial environments. The study area gradually inclines upslope and consequently slope formed a confounding variable between plots situated near and far from source populations.

Presence and abundance of plant species alien to South Africa were recorded for each plot. We noted all alien herbaceous and woody species, but did not list grasses, climbers, lichens, mosses and ferns since these are not generally horticultural species and also because identification was difficult in the absence of flowers and fruits. Plant height and number of stems were recorded for all woody stems over $1.5 \mathrm{~m}$. Recently cut trees (e.g. from alien-plant clearing operations) and those that died in other ways were also recorded, providing the species was still identifiable.

Environmental characteristics (percentage overstorey, mid-storey and understorey cover, percentage exposed rock, $\mathrm{pH}$, soil moisture, soil depth, leaf litter, percentage bare ground, number of tree falls, degree of erosion, and number of paths crossing plot) were sampled every $10 \mathrm{~m}$ along a line bisecting the plot. Soil $\mathrm{pH}$ and soil moisture measurements were taken in the centre of the plot at a depth of $10-15 \mathrm{~cm}$ using a Plant Care ${ }^{\mathrm{TM}}$ probe. Based on ocular estimates, percentages of mid-storey and ground cover were recorded. Total projected overstorey cover was estimated including native and alien plant species and quantified using a digital camera (see image analysis). Leaf litter was subjectively categorized as low, medium or high. Disturbance was further quantified using the number of paths and tree-falls occurring in the plot, as well as through percentage bare ground and degree of erosion (none, little, medium, or heavy).

Data were collected from suburban gardens adjoining the Forest, and at the Forest Station. Sample size was increased by walking or driving slowly along streets and roads surrounding Newlands Forest and recording alien plant species found along these roadsides. Only the presence and abundance of the alien species identified during sampling in Newlands Forest were recorded (Appendix 1). 


\subsection{Statistical analysis}

Alien richness (number of alien species per $\mathrm{m}^{2}$ ), and alien stem density (total number of alien stems per $\mathrm{m}^{2}$ ) were calculated for each plot, habitat type, and distance and disturbance category. Individual alien plot richness and stem density values were averaged for each category (distance and disturbance) within all habitats to account for unequal sample sizes.

Interactions and significant differences in alien richness and alien stem density were determined using STATISTICA ${ }^{\mathrm{TM}}$ 's Kruskal-Wallis ANOVA and median test for distance, disturbance and habitat categories. The Kruskal-Wallis ANOVA and median test was used because assumptions of normality and homogenous variance could not be met. This test was also done by individual species to determine significant differences between disturbance and distance categories. Where Kruskal-Wallis ANOVA tests revealed significant differences, post hoc multiple comparisons of mean ranks for all groups were performed for the main effects. All statistical tests were assessed at the $\alpha=0.05$ level.

In the forest habitat, Populus $x$ canescens, Tradescantia fluminensis and Vinca major can be considered outliers of one particular plot near the ruins of Paradise, a settlement in Newlands Forest dating to the 18th century. It is very likely that these plants were planted in the gardens of this abandoned settlement. Records for these species were therefore excluded from analyses since their distribution in this area probably had nothing to do with spread from suburban gardens, or to any disturbance factor. Also, several species were planted within the study area (e.g. Quercus robur) or for forestry purposes (e.g. Pinus spp.) so their source area is unlikely to be the adjacent suburban areas and Forest Station. The same applied to widespread weed species (e.g. Hypochaeris radicata, Plantago lanceolata, Rubus fruticosus, Taraxacum officinale) that are not cultivated as ornamentals and which were probably introduced with road material, or by hikers or in horse dung; these species were excluded from the distance analyses.

An ordination was performed using $\mathrm{CANOCO}^{\mathrm{TM}}$ to evaluate the relationship to and importance of environmental vari- ables for alien stem density for Newlands Forest. A unimodal canonical correspondence analysis was used to determine relationships between species and environmental variables because the data contains many zero values (ter Braak and Smilauer, 1998). The statistical significance of this relation was determined by a Monte Carlo permutation test. The influence of environmental variables was also determined using STATISTICA's multiple regression.

\subsection{Image analysis}

Overstorey cover was quantified using digital images $(2048 \times 1536$ pixels) in ImageJ (version 1.30). To augment small gaps within the foliage, all images were transferred to 8-bit and sharpened to increase the contrast for mixed pixels (Walter et al., 2003). The images were then converted to binary form using a preset threshold in which all pixels containing a value at or below the preset threshold are converted to black (plant material) while those above are converted to white (sky) (Frazer et al., 2001). Light intensity varied from image to image because the images were taken at different times of the day, over numerous days. Thresholds were adjusted when necessary to ensure that the correct areas were properly represented.

The absolute number of black pixels (i.e. plant material) was counted using a histogram indicating pixel count for each colour value of the binary image (black $=0$, white $=255$ ). Percentage overstorey cover was then calculated using ImageJ's 'measure' function.

\section{Results}

In total, 43 alien plant species from 27 families were recorded in Newlands Forest (Appendix 2). 56\% of species found were present in the putative source populations (Appendix 1). Alien species recorded in most plots throughout the study area, and at high overall frequency in Newlands Forest are listed in Table 1. Rubus fruticosus and Hypochaeris radicata were recorded in most plots at high frequency and abundance in Newlands Forest, whereas there were many individuals of Vinca major and Tradescantia fluminensis, but only in one plot (Table 2).

Table 1 - The 10 most frequently occurring alien plant species in Newlands Forest, ranked by frequency of occurrence, and the most abundant species summed for all plots $(n=59$ plots)

\begin{tabular}{lllr} 
Most frequently occurring species & Frequency ${ }^{\mathrm{a}}$ & Most abundant species & $\begin{array}{c}\text { Total number of individuals } \\
\text { (summed for all plots) }\end{array}$ \\
\hline Rubus fruticosus & 75 & Hypochaeris radicata & 2065 \\
Hypochaeris radicata & 68 & Rubus fruticosus & 1726 \\
Taraxacum officinale & 59 & Populus x canescens & 828 \\
Pittosporum undulatum & 49 & Acacia longifolia & 528 \\
Acacia longifolia & 47 & Taraxacum officinale & 518 \\
Solanum mauritianum & 41 & Vinca major & 396 \\
Quercus robur & 37 & Tradescantia fluminensis & 350 \\
Populus x canescens & 31 & Quercus robur & 307 \\
Paraserianthes lophantha & 31 & Droguetia sp. & 273 \\
Homolanthus populifolius & 24 & Paraserianthes lophantha & 228 \\
\hline
\end{tabular}

a Expressed as percentage occurrence of all plots in Newlands Forest. 
Table 2 - Summary of trends, and significance according to Kruskal-Wallis ANOVA, of alien plant richness and alien stem density for distance and disturbance categories in each habitat and for Newlands Forest overall

\begin{tabular}{|c|c|c|c|c|c|c|}
\hline \multirow[t]{2}{*}{ Area/habitat } & \multicolumn{3}{|c|}{ Alien richness (species $/ \mathrm{m}^{2}$ ) } & \multicolumn{3}{|c|}{ Alien density $\left(\right.$ stems $\left./ \mathrm{m}^{2}\right)$} \\
\hline & Category & Trend & $P$ value & Category & Trend & $P$ value \\
\hline \multirow[t]{2}{*}{ Newlands Forest } & Distance from suburban edge & Decreases with distance & 0.034 & Distance from suburban edge & Highest furthest from edge, lowest at $300 \mathrm{~m}$ & 0.378 \\
\hline & Levels of human disturbance & Increases with disturbances & 0.038 & Levels of human disturbance & Increases with disturbances & 0.306 \\
\hline \multirow[t]{2}{*}{ Pine } & Distance from suburban edge & Decreases with distance & 0.004 & Distance from suburban edge & Highest furthest from edge, lowest at $300 \mathrm{~m}$ & 0.275 \\
\hline & Levels of human disturbance & $\begin{array}{l}\text { Highest at intermediate } \\
\text { disturbances }\end{array}$ & 0.398 & Levels of human disturbance & Increases with disturbances & 0.381 \\
\hline \multirow[t]{2}{*}{ Forest } & Distance from suburban edge & Decreases with distance & 0.622 & Distance from suburban edge & Highest furthest from edge, lowest at $300 \mathrm{~m}$ & 0.736 \\
\hline & Levels of human disturbance & Increases with disturbances & 0.039 & Levels of human disturbance & Increases with disturbances & 0.440 \\
\hline Riverine & Distance from suburban edge & $\begin{array}{l}\text { Highest furthest from edge, } \\
\text { lowest at } 300 \mathrm{~m}\end{array}$ & 0.400 & Distance from suburban edge & Highest furthest from edge, lowest at $300 \mathrm{~m}$ & 0.732 \\
\hline
\end{tabular}
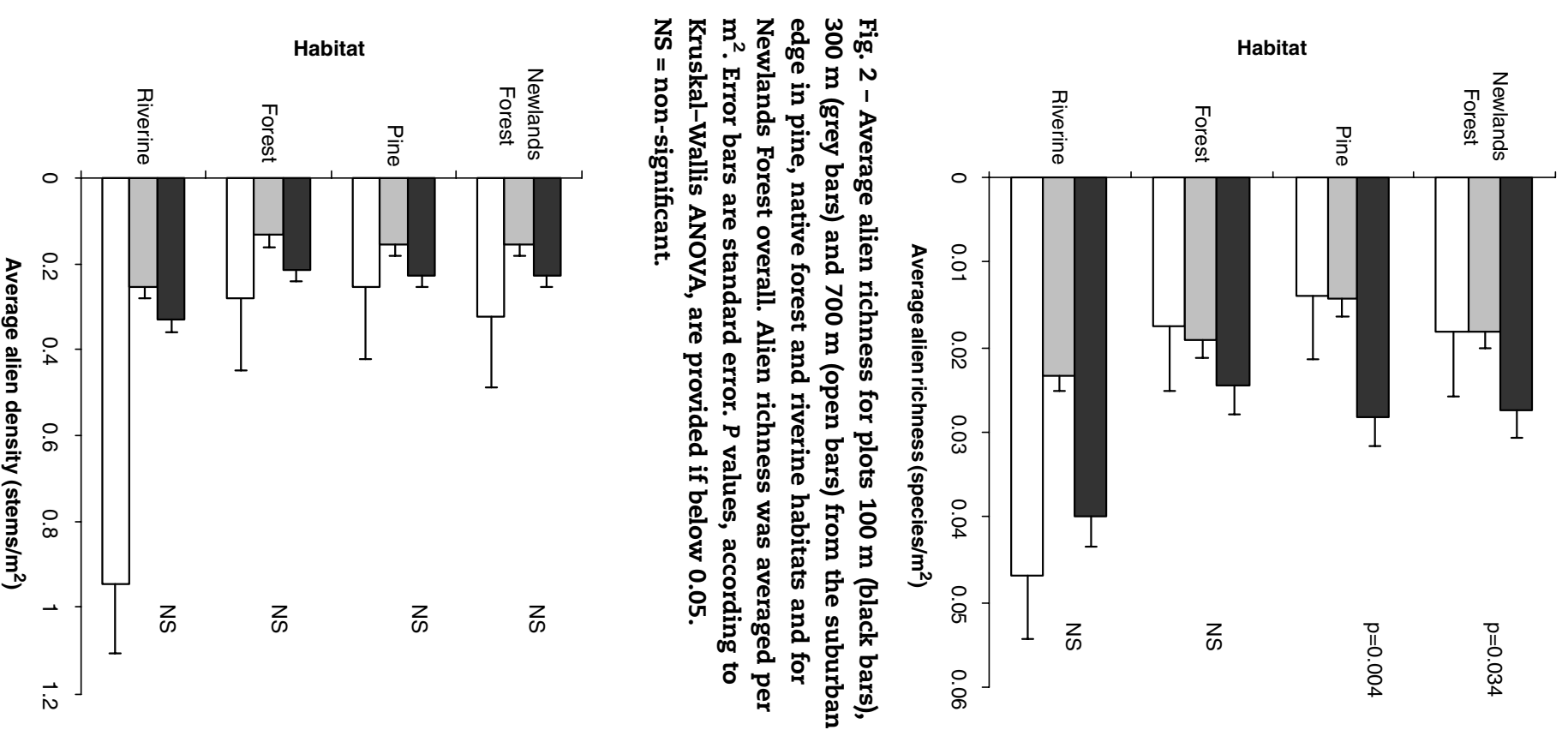
Table 3 - Trends, and significance according to Kruskal-Wallis ANOVA, of alien plant species density in pine and forest habitats for both distance and disturbance categories

\begin{tabular}{|c|c|c|c|}
\hline Category & Species density (trends) & Native forest habitat & Pine habitat \\
\hline \multirow[t]{7}{*}{ Distance from suburban edge } & Decreases with distance & Acacia longifolia (NS) & Cinnamomum camphora (NS) \\
\hline & & Cedronella canariensis (NS) & Homolanthus populifolius (NS) \\
\hline & & Ligustrum sinense (0.055) & Quercus palustris (0.025) \\
\hline & & Ficus carica (NS) & Sonchus oleraceus (NS) \\
\hline & & Syzygium paniculatum (NS) & \\
\hline & Increases with distance & Acer negundo (NS) & \\
\hline & & Ligustrum japonicum (0.023) & \\
\hline \multirow[t]{20}{*}{ Levels of human disturbance } & Increases with disturbances & Acacia longifolia (0.022) & Castanea sativa (NS) \\
\hline & & Acer negundo (NS) & Homolanthus populifolius (NS) \\
\hline & & Cotoneaster franchetii (NS) & Ligustrum sinense (NS) \\
\hline & & Hypochaeris radicata (NS) & \\
\hline & & Ligustrum japonicum (NS) & \\
\hline & & Ligustrum sinense (NS) & \\
\hline & & Pinus spp. (0.0045) & \\
\hline & & Pittosporum undulatum (NS) & \\
\hline & & Quercus robur (NS) & \\
\hline & & Taraxacum officinale (NS) & \\
\hline & Highest at intermediate disturbances & & Hypochaeris radicata (NS) \\
\hline & & & Paraserianthes lophantha (NS) \\
\hline & & & Pittosporum undulatum (NS) \\
\hline & & & Plantago lanceolata (NS) \\
\hline & & & Quercus palustris (NS) \\
\hline & & & Quercus robur (NS) \\
\hline & & & Taraxacum officinale (NS) \\
\hline & Decreases with disturbance & Castanea sativa (NS) & Acacia longifolia (NS) \\
\hline & & Ficus carica (0.002) & Cotoneaster franchetii (NS) \\
\hline & & Populus $x$ canescens (NS) & Ficus carica (NS) \\
\hline
\end{tabular}

Forest $(n=59, p=0.034)$. Analysis of individual habitats revealed that alien richness decreased with distance from the suburban edge in the pine habitat $(n=26, p=0.004)$ (Fig. 2). Differences in overall alien stem density at varying distances from source populations in Newlands Forest, and for individual habitats, were non-significant (Fig. 3, Table 2).

Individual species analyses revealed that Ligustrum sinense $(p=0.055)$ and Quercus palustris $(p=0.025)$ decreased in den-

Table 4 - Alien plant species occurring only $100 \mathrm{~m}$ from the suburban edge in native forest, pine or riverine habitats

\begin{tabular}{lcl} 
Native forest habitat & Pine habitat & Riverine habitat \\
\hline Cinnamomum camphora & $\begin{array}{l}\text { Syzygium } \\
\text { paniculatum }\end{array}$ & Achyranthes aspera \\
Cotoneaster franchetii & & Cotoneaster franchetii \\
Pyracantha angustifolia & & Ligustrum sinense \\
Sonchus oleraceus & & Plantago lanceolata \\
& & Syzygium paniculatum \\
\hline
\end{tabular}

These species were restricted to areas close to the suburban edge, and no individuals of these species were found in other locations in Newlands Forest. sity with increasing distance from putative source populations, in forest and pine habitats, respectively. Similar, but non-significant, trends were discerned for several other species (Table 3). Conversely, Ligustrum japonicum ( $p=0.023)$ increased in density with distance from source populations in the forest habitat. Some alien plant species (Acacia saligna, Castanea sativa, Dianella tasmanica, Erigeron hybrid, Lantana camara, Persea americana, and Senecio sp.) were only found close to putative source populations in all three habitats. Several other alien plant species occurred close to source populations only in particular habitats (Table 4).

\subsection{Levels of human disturbance and alien richness and alien stem density}

Overall, there was a significant difference in alien richness with increasing levels of human disturbance in Newlands Forest $(n=50, p=0.038)$. Analysis of individual habitats indicated an increase in alien richness with increasing disturbance levels in the native forest habitat $(n=24, p=0.039$ ) (Fig. 4, Table 2). Differences in alien stem density with increasing levels of human disturbance were non-significant (Fig. 5, Table 2).

Individual species analyses revealed that Acacia longifolia $(p=0.022)$ and Pinus spp. $(p=0.005)$ increased in density with increasing levels of human disturbance in the native forest 


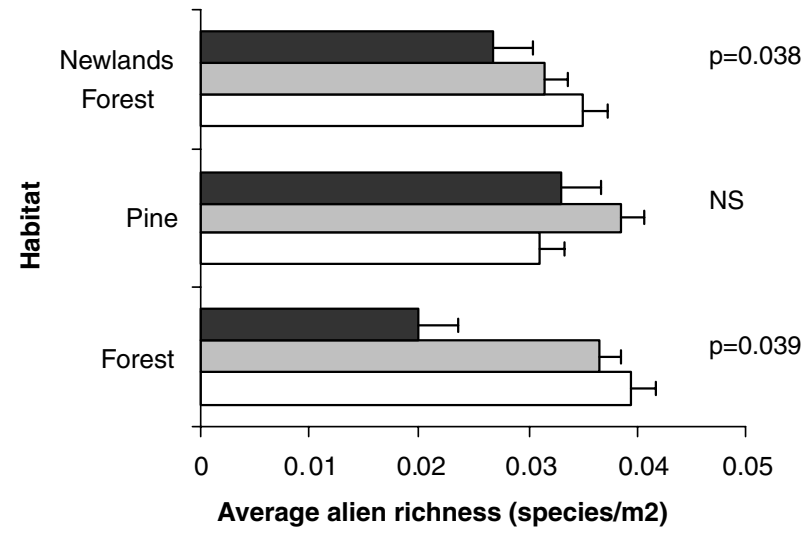

Fig. 4 - Average alien richness for low (black bars), intermediate (grey bars) and highly disturbed (open bars) plots in native forest and pine habitats and for Newlands Forest overall. Alien richness was averaged per $\mathrm{m}^{2}$. Error bars are standard error. $P$ values, according to Kruskal-Wallis ANOVA, are provided if below 0.05 . NS = non-significant statistically.

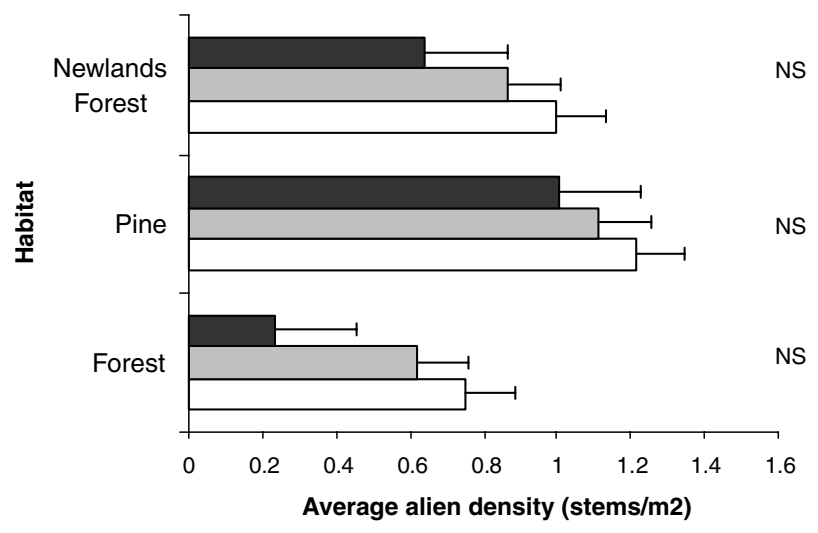

Fig. 5 - Average alien density for low (black bars), intermediate (grey bars) and highly disturbed (open bars) plots in native forest and pine habitats and for Newlands Forest overall. Alien density was averaged per $\mathrm{m}^{2}$. Error bars are standard error. $P$ values, according to Kruskal-Wallis ANOVA, are provided if below 0.05 . NS = non-significant.

habitat, while similar but non-significant trends were identified for several other species (Table 3). In contrast, Ficus carica $(p=0.002)$, decreased with an increase in levels of human disturbance.

\subsection{Environmental predictors of alien richness and alien stem density}

Canonical correspondence analysis (CCA) on species occurrence data and ordinal environmental variables revealed that overstorey cover, understorey cover, exposed rock and number of tree falls were important factors influencing invasion in Newlands Forest (Fig. 6). The first three CCA axes accounted for $56.3 \%$ of the total variance explained by the spe- cies correspondence analysis. The first axis was positively associated with percentage overstorey cover $(r=0.65)$ and accounted for $26.7 \%$ of variation. Percentage understorey cover $(r=0.49)$ and number of tree falls $(r=0.31)$ were positively associated with the second axis, which accounted for $16.9 \%$ of variation. The third axis, accounting for $12.7 \%$ of variation, was positively associated with percentage bare ground $(r=0.53)$ and negatively associated with soil depth $(r=-0.32)$, whereas the fourth axis, explaining $11.9 \%$ of variation, was only weakly associated with soil depth $(r=0.2)$. Environmental variables were inter-correlated. Percentage bare ground $(r=0.41)$ and $\mathrm{pH}(r=0.61)$ increased with the number of paths crossing, whereas soil depth decreased $(r=-0.55) . \mathrm{pH}$ increased with number of tree falls $(r=0.45)$, as did soil moisture with soil depth $(r=0.47)$. The Monte Carlo test of significance revealed that all canonical axes were significant in Newlands Forest $(p=0.003)$.

Three groups of alien plant species could be distinguished in the ordination diagram (Fig. 6). The largest group (comprising species such as Acacia longifolia, A. saligna, Castanea sativa, Homolanthus populifolius, Hypochaeris radicata, Plantago lanceolata, Quercus palustris, Taraxacum officinale) was associated with low cover in the understorey, mid-storey and overstorey, few tree falls and paths crossing, shallow soils, little soil moisture and bare ground. One smaller group was associated with fairly high soil moisture and exposed rock cover, numerous paths and lots of bare ground, while the smallest group was associated with moderate overstorey cover, high mid-storey cover and deep soils.

Results from multiple regression analyses provide further detail to explain the broad patterns shown in the ordination. Soil $\mathrm{pH}$ was the most important positive predictor of alien richness in Newlands Forest $(p=0.023)$. Alien stem density decreased with an increase in percentage exposed rock $(p=0.021)$ in Newlands Forest, and decreased with increasing soil $\mathrm{pH}(p=0.001)$ and soil moisture $(p=0.025)$ in the pine habitat.

\section{Discussion}

Human-aided introduction allows alien plants to overcome the first of a series of barriers in the invasion process. However, successful invasion depends on a number of factors that assist in surmounting these barriers - factors such as proximity to sources of propagules, frequency of disturbance, and the degree of habitat openness (Timmins and Williams, 1991) as well as intrinsic characteristics of the invading species and the site in which it is invading (Hobbs and Humphries, 1995; Yates et al., 2004).

4.1. Distance from putative source populations and alien plant invasion

Distance from putative source populations is an important factor structuring alien richness in Newlands Forest, particularly in the pine habitat where alien richness decreased significantly with distance from the suburban edge. Distance from property lines also explained alien species richness in ponderosa pine/Douglas-fir forests of the Colorado Front Range in the USA (Fornwalt et al., 2003). 


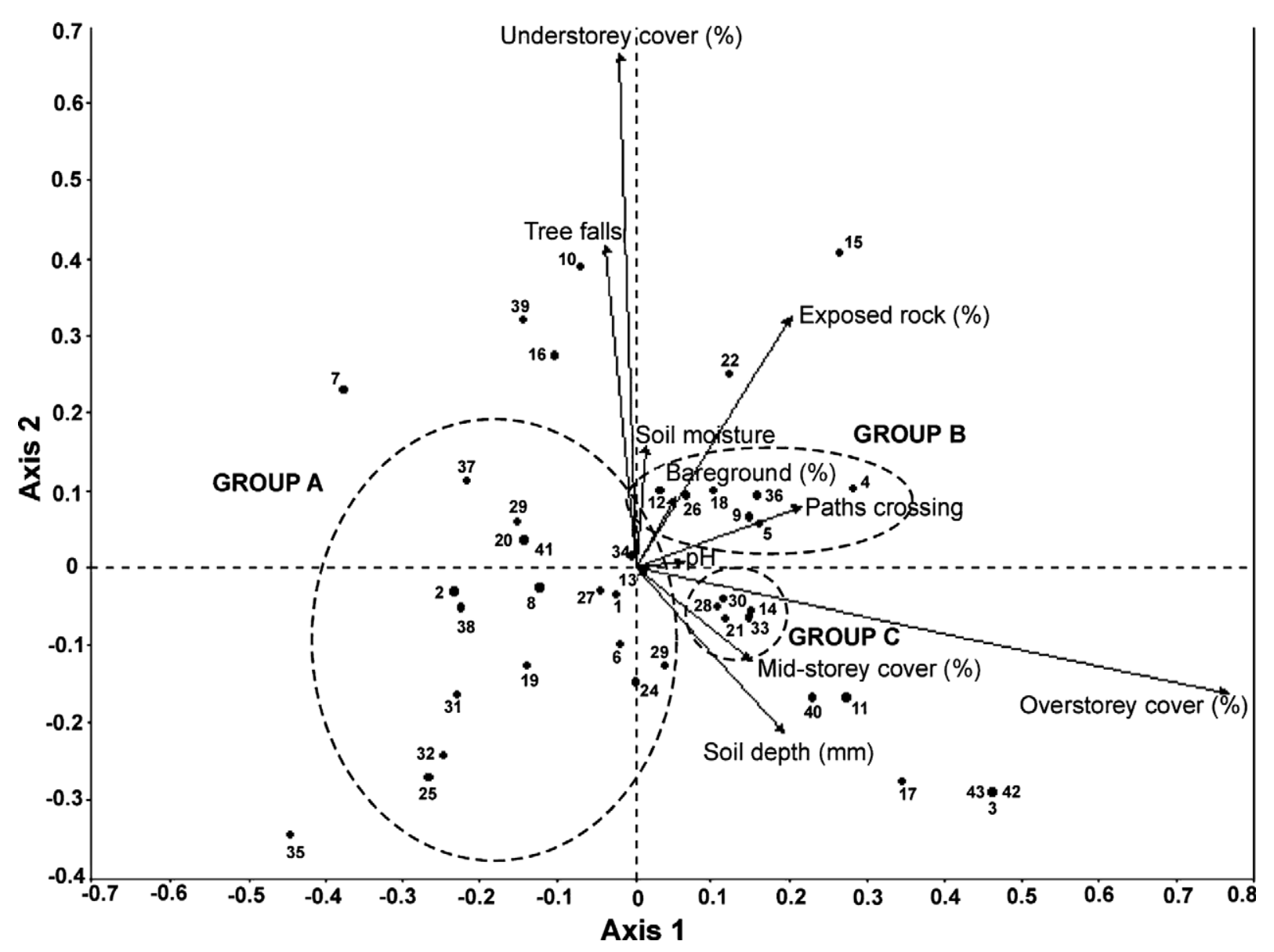

Fig. 6 - Canonical correspondence analysis (CCA) diagram of alien plant species in Newlands Forest based on species frequency data (axes 1 and 2) for $n=43$ species. Environmental variables are indicated by biplot arrows. Species are numbered according to Appendix 2. Three groups can be identified, the largest group (group A) comprises species such as Acacia longifolia, A. saligna, Castanea sativa, Homolanthus populifolius, Hypochaeris radicata, Plantago lanceolata, Taraxacum officinale; one smaller group consisting of Acer negundo, Achyranthes aspera, Cedronella canariensis, Ficus carica, Phoenix canariensis, Solanum mauritianum, Cinnamomum camphora (group B), and the smallest group (group C) comprises Dianella tasmanica, Lantana camara, Pittosporum undulatum, Populus x canescens, Quercus robur.

Differences in alien richness with distance from putative source populations between habitats could potentially be a result of diverse habitat structure. Pine plantations contain a fairly open overstorey canopy, whereas native forest is quite dense, and the mid- and overstorey canopies are closed. Alien plant species are able to disperse into open habitats more readily, and environmental features of open habitats are good predictors of alien plant invasion. Furthermore, open habitats generally contain higher light levels, and the dense native forest may limit the establishment of alien plants. In riverine habitats, steep banks and perennially flowing water may also limit alien plant establishment.

Proximity to large propagule sources is intuitively an important factor influencing the spread of alien species into natural areas. For example, proximity to towns was one of the most important influences on the number of 'weeds' found across New Zealand forest reserves (Timmins and Williams, 1991). Also in New Zealand, natural vegetation in Northland close to settlements contained more alien plant species than those further away, indicating that these species are moving from settlements into natural areas (Sullivan et al., 2001). The percentage of alien species decreased significantly with distance from the suburban edge in Sydney (Rose and Fairweather, 1997), while in another Australian study the invasion of Pittosporum undulatum was strongly affected by the suburban edge; its abundance significantly increased with age of the surrounding suburban settlement, and the proportion of reproductive $P$. undulatum plants decreased significantly with distance from the suburban edge (Rose, 1997). In Maryland, USA, Thompson (1999) found the percentage of alien plant species was highest in forest areas adjacent to suburban and urban land-use types.

There is some indication of movement of horticultural plants from suburban gardens into surrounding habitats in Newlands Forest. Several species occurred in some, and not all habitats at $100 \mathrm{~m}$ from the suburban edge (Table 4), and the majority of these species were present in source areas. A few alien plant species were only found within a $100 \mathrm{~m}$ of source populations in all habitats. These might be emerging invaders, moving from suburban gardens into the park. 
However, of these species only Erigeron hybrid was present in the source areas, suggesting the movement of species might be mainly from other locations. It is questionable whether suburban gardens adjacent to the forest and the Forest station were the only source areas for those alien species that have been present in the area for over a century. However, many of these species (e.g. Acacia longifolia, Castanea sativa, Cotoneaster franchetii, Lantana camara, Paraserianthes lophantha, Solanum mauritianum) are, or were until recently, horticultural subjects, and some are still grown in suburban gardens (Appendix 1). The lack of a significant proportion of alien plant species present in source populations (Appendix 1) also implies that the decrease with distance from suburban edge may be influenced by factors such as slope, rather than suburban gardens surrounding the forest. The area is situated on the slopes of Table Mountain, which inclines from the adjacent suburban gardens; therefore the decline in alien plant species could indicate increasingly unfavourable site conditions associated with the gradual incline (e.g. shallow soils of scree slopes).

Alien stem density was highest furthest from the suburban edge, suggesting factors other than distance from putative sources may also be responsible for structuring alien plant distribution in Newlands Forest. The long history of exposure to alien species in Newlands Forest, for example due to the presence of old homesteads, might be interfering with current patterns of invasion associated with distance from the suburban edge. In forest biomes worldwide, vertebrates, and birds in particular, play an important role in the spread of alien plants (Kruger et al., 1986; Mack and Lonsdale, 2001), and are well-known long-distance dispersal agents (Johnson and Adkisson, 1985). All three species identified in individual alien density analyses (Ligustrum sinense, L. japonicum and Quercus palustris) are vertebrate-dispersed (two by birds). The availability of dispersal agents may also influence alien plant invasion in Newlands Forest and obscure trends related to distance from suburban edge. The small size of the study area may also mean that all parts of the area are within dispersal range of most species, masking any patterns.

Past and present human activities are also important influences on the degree of invasion in reserves and may actually diminish the significance of proximity to source areas in a study. Forest reserves containing particularly high number of weeds in New Zealand were those areas that had a history of human use such as sawmills or old homesteads, which provided propagule sources (Timmins and Williams, 1991). In Newlands Forest, the long history of human influence, including the presence of permanent settlements, timber extraction and recreational usage, has clearly left a "footprint" in the area with implications for invasibility and the current pattern of alien plant invasions. It was not possible to quantify the dimensions of these past human influences to determine their role in the invasions that we see today. However, despite these problems, the approach we followed provided considerable insight into the patterns of alien plant invasions in the area.

\subsection{Levels of human disturbance and alien plant invasion}

Different types of disturbance affect alien plant invasions in different ways. Some studies have found support for the general and long-held paradigm that human-disturbed areas are more readily invaded (Hobbs and Huenneke, 1992; Parendes and Jones, 2000), while others (Brothers and Spingarn, 1992; Rose, 1997; Fornwalt et al., 2003) seem to contradict this idea. The results of our study lend partial support to the notion that disturbance (very broadly defined) facilitates alien plant invasion. In Newlands Forest, and in the native forest habitat in particular, highly disturbed areas contained the highest richness of alien plant species. Anthropogenic disturbance is known to enhance invasion in a variety of ecosystems. For example, Tyser and Worley (1992) found that alien richness in a grassland reserve was highest in sites adjacent to primary and secondary roads. Likewise, physically disturbed sites (tracks) in urban bushland supported alien plants, while sites without disturbance did not (Lake and Leishman, 2004). Similarly, the abundance of alien species was strongly related to the degree of disturbance (roadway usage) on the Georgia Sea Islands (Rodgers and Parker, 2003), while in a forest landscape the frequency of alien species was higher along used roads compared to abandoned roads (Parendes and Jones, 2000). Roads and trails facilitate invasion through the creation of open spaces, which effectively fragment natural areas and change forest microclimates, in particular the availability of light, adding to the competitive advantage of invasive species (Brothers and Spingarn, 1992; Yates et al., 2004). In addition, roadsides are human-disturbed corridors, which create additional disturbances through the pressure of usage. The number of alien species occurring in reserves has been positively correlated with the number of visitors to a reserve (Macdonald et al., 1989; Lonsdale, 1999). In New Zealand's forest and scrub reserves, the number of 'weeds' increased with human usage (Timmins and Williams, 1991). Newlands Forest is a popular recreational area with thousands of visitors creating disturbance and facilitating dispersal of alien plant species.

In contrast to the positive relationship between alien richness and degree of disturbance, greatest species richness is expected at intermediate levels or intensity of disturbance, since few species can survive frequent disturbance and few can persist without disturbance (Connell, 1978; Hobbs and Huenneke, 1992). It would appear that our data corroborates with other studies where the intermediate disturbance hypothesis is not supported for alien richness (McIntyre and Lavorel, 1994; Vujnovic et al., 2002).

The lack of significant differences in alien stem density with disturbance categories in the pine habitat could be due to the silvicultural practises of pruning and thinning. Forest logging practices create larger clearings than normal windthrow events and the temporal and spatial patterns of harvesting are relatively distinct from natural treefalls (Sousa, 1984), resulting in a habitat where disturbance categories might not be as pronounced, and an entire area that is essentially "disturbed". The high incidence of non-significant results of alien stem density in the pine habitat is therefore to be expected. Previous disturbance in the area is difficult to detect and quantify, and although only recent disturbances are considered, past events appear to have impacted patterns of alien stem density and richness. This study reinforces the importance of considering past histori- 
cal effects when inferring the role of disturbance and distance to source populations in structuring alien plant invasions.

\subsection{Environmental features and alien plant invasion}

Most alien plant species in Newlands Forest appear to favour open spaces with little understorey and overstorey cover, or numerous paths and exposed rocks and a high proportion of bare ground (Fig. 6). Several species associated with these environmental characteristics are also those alien plant species that occurred frequently throughout Newlands Forest or were abundant.

Overstorey cover is the most important environmental characteristic influencing alien plant invasion in Newlands Forest; alien species diversity increases with a decrease in overstorey cover. Gaps in the overstorey increase light availability, allowing shade-intolerant alien plants to potentially overcome what was a previous environmental barrier. Light levels, estimated from overstorey cover percentages, have been found to be an important predictor of alien plant richness and distribution in several studies (e.g. Brothers and Spingarn, 1992; Parendes and Jones, 2000). The highly disturbed nature of Newlands Forest probably facilitates gaps in overstorey cover to promote alien plant invasion, although no correlation was determined between disturbance and overstorey cover.

\subsection{Management implications}

Patches of Afromontane forest are of high conservation importance on the Cape Peninsula. Newlands Forest is one of the largest remnants of this vegetation type in the area (Geldenhuys, 2000), and patches like these clearly demand special attention since their location in a matrix of humandominated land places them at high risk from many factors associated with human activities. Loss of native species, and shift in species composition due to changed microclimates are some of the many effects that the human-dominated matrix can exert on such fragmented conservation areas. It is crucial that these remnants be protected against the onslaught of alien plant species crossing the reserve borders.

The widespread and abundant species identified in Newlands Forest (Table 1) provide obvious targets for management action. However, it has been suggested that a change in emphasis from an individual species approach to an ecosystem and socio-economic approach is needed, as is a shift from alien plant control to prevention (Hobbs and Humphries, 1995). A critical step in preventing the spread of alien species across the urban/wildland interface would be to remove species that are known or suspected to be invasive from suburban gardens. This is much more cost-effective than conducting regular control operations in the nearby protected area. Legislation already exists for control of existing invasive alien species (the Conservation of Agricultural Resources Act; see Richardson et al., 2003), and new regulations are in preparation for the $2004 \mathrm{Na}$ tional Environmental Management: Biodiversity Act. Implementation and enforcement of these regulations will require considerable extension work. The national Working for Water programme (http://www.dwaf.pwv.gov.za/wfw/) is tackling a range of issues in this regard throughout South Africa. For example, cooperation between Working for Water and the South African Nurserymen's Association is aiming to reduce the use of known invasive species in horticulture.

The susceptibility of invaded ecosystems can be changed by management activities, altering factors that facilitate alien plant invasion such as disturbance. Anthropogenic disturbance and accidental dispersal could be kept to a minimum through the restriction of vehicles, control of visitor movements through a clearly demarcated path-network with zonation for different visitor needs where dog-walkers in particular would be limited to certain paths, and dogs kept on a leash (Timmins and Williams, 1991; Geldenhuys, 2000). The number of roads, which are important both as sources of disturbance and corridors of dispersal, need to be reduced to absolute minimum and attention given to their placement; some existing roads should be closed and restored. Longterm restoration of roads (both actively and passively restored) has facilitated forest recovery in southwestern Ontario, and has appeared to lessen conflicts between human utilization and conservation in this area (McLachlan and Bazely, 2003). This would demand a major investment of resources, but is indicative of the level of management that is required if small remnants of semi-natural vegetation are to be conserved.

A strategy designed to control and prevent alien plant invasion should not cause further damage to the native community. Some forms of management may cause even more damage than the invasive plant that it is aimed at removing. For example, the total removal of alien plant species in a forest environment might have detrimental effects on indigenous forest pioneer species which require nurseplants for effective establishment (Geldenhuys, 2000). Recent research has also shown the need to place alien species eradication programmes in the context of the overall ecosystem (Zavaleta et al., 2001). For example, removing alien species in isolation can result in unforeseen changes to both native species and ecosystems, such as the loss of native species due to a functional dependence on an alien species, or an increase in other invasive species (Zavaleta et al., 2001).

\section{Conclusions}

Newlands Forest is under considerable threat from human activities and alien plant invasion, and substantial and sustained management intervention is needed to prevent rapid degradation of the site. Multiple factors are responsible for structuring the alien plant invasions in the area; habitat features, recent disturbance, and distance from putative source populations interact to facilitate invasions. Influences and the relative importance of these factors are difficult to separate, probably partly because of the relatively small size of the study area and the long history of past disturbances and alien plantings.

Successful invasion appears to depend on a number of factors that facilitate the surmounting of invasion 'barriers' 
- factors such as proximity to sources of propagules, frequency of disturbance, and the degree of habitat openness, particularly overstorey cover. Proximity to putative sources and increased disturbance appears to facilitate the arrival of new species (richness), while intrinsic species characteristics probably influence the continued success of these species (density). Further research on intrinsic characteristics, such as life-history traits and seed biology, might provide a clearer understanding of these patterns to prevent a situation of alien species dominating fellow alien species.

\section{Acknowledgements}

We thank SANParks for permission to work in Newlands Forest and for access to GIS data and other information. For assistance with fieldwork we thank Peter Alston and Ian Little. Sue Milton provided very helpful advice. Terry Trinder-Smith (Curator, Bolus Herbarium, Botany Department, University of Cape Town) is thanked for assistance in identifying plant species. We are also grateful to Peter Ryan, John Hoffmann and Andrew Denny for statistical advice; Nick Lindenberg and Wesley Roberts for GIS support; and Chris Tobler and Colleen Flanagan for suggestions with image analyses. Dawn Bazely, Peter Williams and two anonymous reviewers provided very useful comments and suggestions on an early draft of the paper. D.M.R. acknowledges support from the DST-NRF Centre of Excellence for Invasion Biology. K.P.A. acknowledges support from the National Research Foundation and the Cape Tercentenary Foundation.

\section{Appendix 1}

Inventory of alien plant species found in putative source populations (suburban gardens, roadside plantings, Forest Station and Union Avenue)

\begin{tabular}{cl}
\hline $\begin{array}{l}\text { Number of } \\
\text { Individuals }\end{array}$ & \multicolumn{1}{c}{ Species } \\
\hline$>20$ & $\begin{array}{l}\text { Cotoneaster franchetii; Syzygium } \\
\text { paniculatum } \\
\text { Acanthus mollis; Dianella tasmanica; } \\
\text { Erigeron hybrid; Ficus carica; } \\
\text { Pyracantha angustifolia; Quercus robur } \\
\text { Acer negundo; Centranthus ruber; } \\
\text { Ligustrum japonicum; Ligustrum } \\
\text { sinense; Populus x canescens; Quercus } \\
\text { palustris; Sonchus asper } \\
\text { Acacia longifolia; Achyranthes aspera; } \\
\text { Ageratina adenophora; Castanea } \\
\text { sativa; Eriobotrya japonica; } \\
\text { Homolanthus populifolius; Phoenix } \\
\text { canariensis; Pittosporum undulatum; } \\
\text { Solanum mauritianum }\end{array}$ \\
\hline $\begin{array}{l}\text { Alien plant species found in source populations were only } \\
\text { recorded if the species occurred in Newlands Forest. }\end{array}$ \\
\hline
\end{tabular}

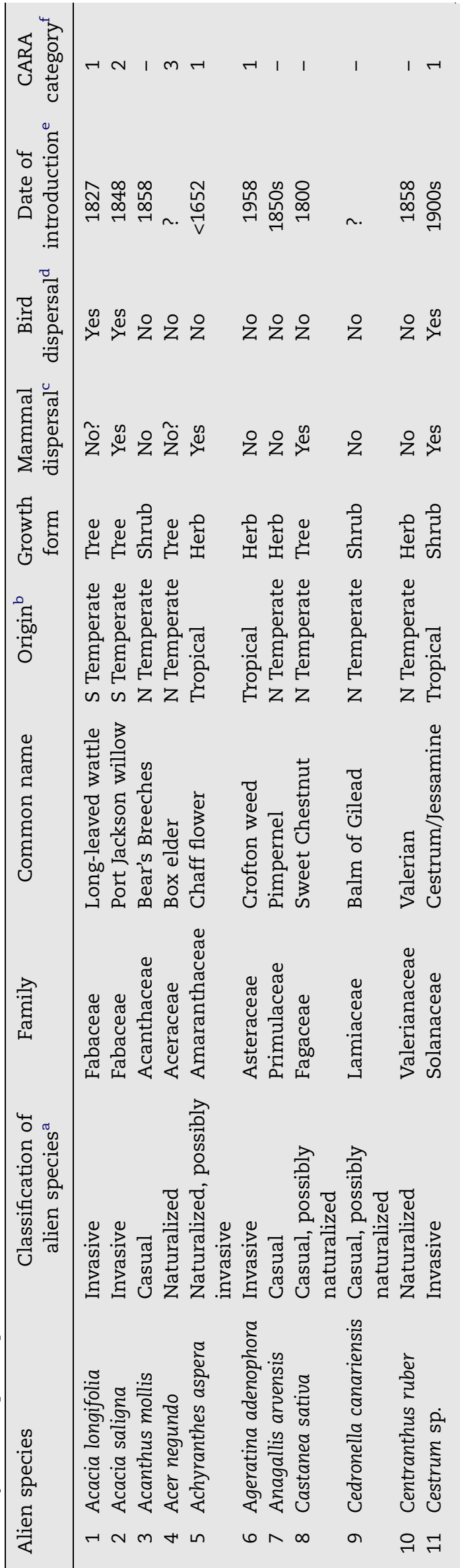




\begin{tabular}{|c|c|c|c|c|c|c|c|c|c|c|}
\hline 12 & Cinnamomum camphora & $\begin{array}{l}\text { Naturalized, possibly } \\
\text { invasive }\end{array}$ & Lauraceae & Camphor Tree & N Temperate & Tree & No & Yes & 1846 & 1 \\
\hline 13 & Cotoneaster franchetii & Invasive & Rosaceae & Orange leaf cotoneaster & $\mathrm{N}$ Temperate & Tree & Yes? & Yes & 1800 & 3 \\
\hline 14 & Dianella tasmanica & $\begin{array}{l}\text { Casual, possibly } \\
\text { invasive }\end{array}$ & Liliaceae & Flax Lily & S Temperate & Tree & Yes & Yes & 1858 & - \\
\hline 15 & Droguetia sp. & Casual & Urticaceae & - & Unknown & Shrub & No & No & $?$ & - \\
\hline 16 & Erigeron hybrid & Casual & Asteraceae & Fleabane & N Temperate & Herb & No & No & $?$ & - \\
\hline 17 & Eriobotrya japonica & Invasive & Rosaceae & Loquat & $\mathrm{N}$ Temperate & Tree & Yes & Yes & 1858 & 3 \\
\hline 18 & Ficus carica & Naturalized & Moraceae & Edible Fig & $\mathrm{N}$ Temperate & Tree & Yes & Yes & 1858 & - \\
\hline 19 & Homolanthus populifolius & Invasive & Euphorbiaceae & Native Bleeding Heart & S Temperate & Tree & Yes & Yes & 1858 & - \\
\hline 20 & Hypochaeris radicata & Invasive & Asteraceae & Hairy wild lettuce & N Temperate & Herb & No & No & 1950 & - \\
\hline 21 & Lantana camara & Invasive & Verbenaceae & Lantana & Tropical & Shrub & Yes & Yes & 1858 & 1 \\
\hline 22 & Ligustrum japonicum & $\begin{array}{l}\text { Naturalized, possibly } \\
\text { invasive }\end{array}$ & Oleaceae & Japanese Privet & N Temperate & Shrub & Yes & Yes & 1927 & 3 \\
\hline 23 & Ligustrum sinense & $\begin{array}{l}\text { Naturalized, possibly } \\
\text { invasive }\end{array}$ & Oleaceae & Chinese Privet & N Temperate & Shrub & Yes & Yes & 1924 & 3 \\
\hline 24 & Paraserianthes lophantha & Invasive & Fabaceae & Stink bean & S Temperate & Tree & No & No & 1833 & 1 \\
\hline 25 & Persea americana & $\begin{array}{l}\text { Casual, possibly } \\
\text { naturalized }\end{array}$ & Lauraceae & Avocado & Tropical & Tree & Yes & No & 1858 & - \\
\hline 26 & Phoenix canariensis & $\begin{array}{l}\text { Casual, possibly } \\
\text { naturalized }\end{array}$ & Arecaceae & Canary Isle Date Palm & N Temperate & Tree & Yes & Yes & $?$ & - \\
\hline 27 & Pinus spp. & Invasive & Pinaceae & Pine spp. & N Temperate & Tree & No & No & 1825 & 2 \\
\hline 28 & Pittosporum undulatum & Invasive & Pittosporaceae & Australian cheesewood & S Temperate & Tree & No? & Yes & 1858 & 1 \\
\hline 29 & Plantago lanceolata & Invasive & Plantaginaceae & Buckhorn plantain & N Temperate & Herb & No & No & $?$ & - \\
\hline 30 & Populus $x$ canescens & Invasive & Salicaceae & Grey Poplar & N Temperate & Tree & No & No & 1920s & 2 \\
\hline 31 & Pyracantha angustifolia & Invasive & Rosaceae & Yellow Firethorn & N Temperate & Tree & No? & Yes & 1919 & 3 \\
\hline 32 & Quercus palustris & Naturalised & Fagaceae & Pin Oak & N Temperate & Tree & Yes & No? & 1858 & - \\
\hline 33 & Quercus robur & Invasive & Fagaceae & English Oak & $\mathrm{N}$ Temperate & Tree & Yes & No & 1656 & - \\
\hline 34 & Rubus fruticosus & $\begin{array}{l}\text { Naturalized, possibly } \\
\text { invasive }\end{array}$ & Rosaceae & European Blackberry & N Temperate & Shrub & Yes & Yes & 1858 & 2 \\
\hline 35 & Senecio sp. & Casual & Asteraceae & Ragwort & Unknown & Herb & No & No & $?$ & - \\
\hline 36 & Solanum mauritianum & Invasive & Solanaceae & Bugweed & Tropical & Tree & Yes & Yes & 1862 & 1 \\
\hline 37 & Sonchus asper & $\begin{array}{l}\text { Casual, possibly } \\
\text { naturalized }\end{array}$ & Asteraceae & Spiny sow thistle & $\mathrm{N}$ Temperate & Herb & No & No & $?$ & - \\
\hline 38 & Sonchus oleraceus & $\begin{array}{l}\text { Casual, possibly } \\
\text { naturalized }\end{array}$ & Asteraceae & Sow thistle & N Temperate & Herb & No & No & 1685 & - \\
\hline 39 & Stenocarpus sinuatus & Casual & Proteaceae & Firewheel tree & S Temperate & Tree & No & No & $?$ & - \\
\hline 40 & Syzygium paniculatum & $\begin{array}{l}\text { Naturalized, possibly } \\
\text { invasive }\end{array}$ & Myrtaceae & Australian Brush Cherry & S Temperate & Tree & Yes & $\begin{array}{l}\text { Yes } \\
\text { (continu }\end{array}$ & $\begin{array}{l}1858 \\
\text { d on nex }\end{array}$ & page) \\
\hline
\end{tabular}




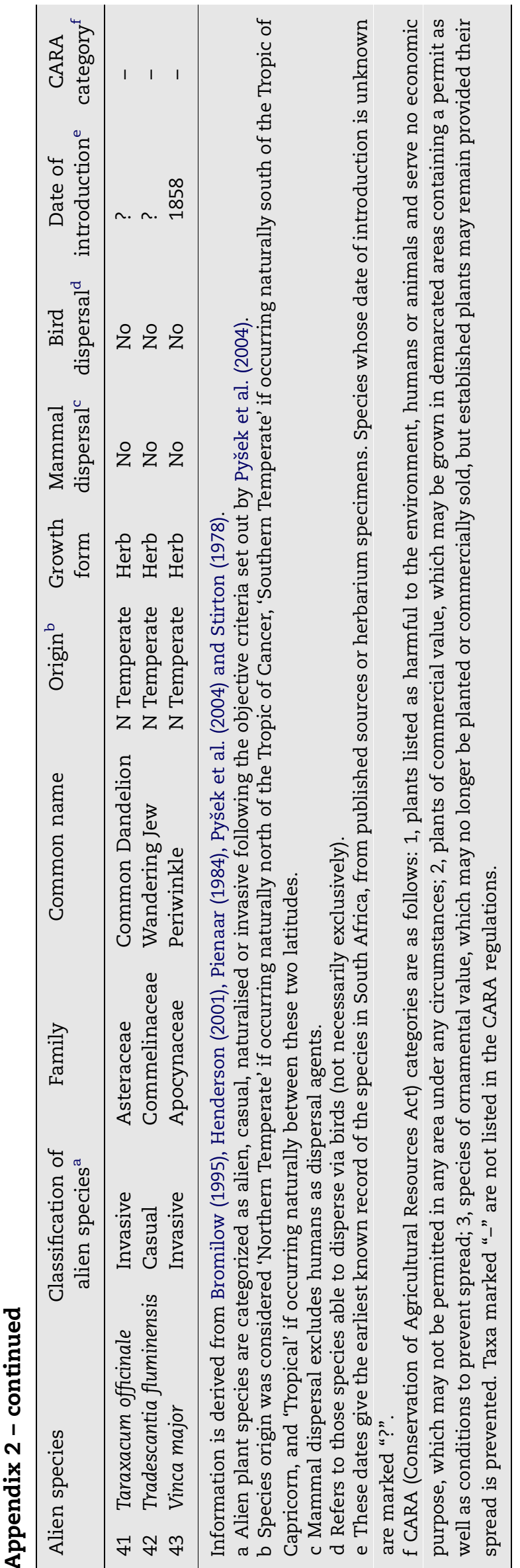

\section{R E F E R E N C E S}

Baskin, Y., 2002. The greening of horticulture: new codes of conduct aim to curb plant invasions. Bioscience 52, 464-471.

Bolger, D.T., Scott, T.A., Sauvajot, R.M., Potenza, P., McCalvin, C., Tran, D., Mazzoni, S., Soulé, M.E., 1997. Response of rodents to habitat fragmentation in coastal southern California. Ecol. Appl. 7, 522-563.

Bromilow, C., 1995. Problem Plants of South Africa. Briza Publications, Cape Town.

Brothers, T.S., Spingarn, A., 1992. Forest fragmentation and alien plant invasion of central Indiana old-growth forests. Conserv. Biol. 6, 91-100.

Connell, J.H., 1978. Diversity in tropical rain forests and coral reefs. Science 199, 1302-1310.

Cowling, R.M., Macdonald, I.A.W., Simmons, M.T., 1996. The Cape Peninsula, South Africa: physiographical, biological and historical background to an extraordinary hot-spot of biodiversity. Biodiv. Conserv. 5, 527-550.

Davis, M.A., 2003. Biotic globalization: does competition from introduced species threaten biodiversity? Bioscience 53, 481-489.

Eikelenboom, M., van der Voort, A., 2002. Bark Harvesting in Newlands Forest. SANParks, Cape Town. 42pp.

Fornwalt, P.J., Kaufmann, M.R., Huckaby, L.S., Stoker, J.M., Stohlgren, T.J., 2003. Non-native plant invasions in managed and protected ponderosa pine/Douglas-fir forests of the Colorado front range. Forest Ecol. Manag. 177, 515-527.

Foxcroft, L.C., Rouget, M., Richardson, D.M., MacFadyen, S., 2004. Reconstructing 50 years of Opuntia stricta invasion in the Kruger National Park, South Africa: environmental determinants and propagule pressure. Diversity Distrib. 10, 427-437.

Fraver, S., 1994. Vegetation responses along edge-to-interior gradients in the mixed hardwood forests of the Roanoke River Basin, North Carolina. Conserv. Biol. 8, 822-832.

Frazer, G.W., Fournier, R.A., Trofymow, J.A., Hall, R.J., 2001. A comparison of digital and film fisheye photography for analysis of forest overstorey structure and gap light transmission. Agric. Forest Meteorol. 109, 249-263.

Geldenhuys, C.J., 2000. Conservation management of Afromontane forest pockets on the Cape Peninsula. Report FW-01/00, Afro-Montane Information Forum, Cape Peninsula National Park, 88pp.

Geldenhuys, C.J., le Roux, P.J., Cooper, K.H., 1986. Alien invasions in indigenous evergreen forest. In: Macdonald, I.A.W., Kruger, F.J., Ferrar, A.A. (Eds.), The Ecology and Management of Biological Invasions in Southern Africa: Proceedings of the National Synthesis Symposium on the Ecology of Biological Invasions. Oxford University Press, Cape Town, pp. 119-131.

Gill, A.M., Williams, J.E., 1996. Fire regimes and biodiversity: the effects of fragmentation of southeastern Australian eucalypt forests by urbanisation, agriculture and pine plantations. Forest Ecol. Manag. 85, 261-278.

Henderson, L., 2001. Alien weeds and invasive plants: a complete guide to declared weeds and invaders in South Africa. Plant Protection Research Institute Handbook 12, Agricultural Research Council, Pretoria.

Higgins, S.I., Richardson, D.M., Cowling, R.M., Trinder-Smith, T.H., 1999. Predicting the landscape-scale distribution of alien plants and their threat to plant diversity. Conserv. Biol. 13, 303-313.

Hobbs, R.J., Huenneke, L.F., 1992. Disturbance, diversity, and invasion: implications for conservation. Conserv. Biol. 6 , 324-337. 
Hobbs, R.J., Humphries, S.E., 1995. An integrated approach to the ecology and management of plant invasions. Conserv. Biol. 9, 761-770.

Hobbs, R.J., Yates, C.J., 2003. Impacts of ecosystem fragmentation on plant populations: generalising the idiosyncratic. Aust. J. Bot. 51, 471-488.

Johnson, W.C., Adkisson, C.S., 1985. Dispersal of beech nuts by blue jays in fragmented landscapes. Am. Midl. Nat. 113, 319-324.

Kruger, F.J., Richardson, D.M., van Wilgen, B.W., 1986. Processes of invasion by alien plants. In: Macdonald, I.A.W., Kruger, F.J., Ferrar, A.A. (Eds.), The Ecology and Management of Biological Invasions in Southern Africa. Oxford University Press, Cape Town, pp. 145-155.

Lake, J.C., Leishman, M.R., 2004. Invasion success of exotic plants in natural ecosystems: the role of disturbance, plant attributes and freedom from herbivores. Biol. Conserv. 117, 215-226.

Latimer, A.M., Silander Jr., J.A., Gelfand, A.E., Rebelo, A.G., Richardson, D.M., 2004. Quantifying threats to biodiversity from invasive alien plants and other factors: a case study from the Cape Floristic region. S. Afr. J. Sci. 100, 81-86.

Lonsdale, W.M., 1999. Global patterns of plant invasions and the concept of invasibility. Ecology 50, 1522-1536.

Macdonald, I.A.W., Loope, L.L., Usher, M.B., Hamann, O., 1989. Wildlife conservation and the invasion of nature reserves by introduced species: a global perspective. In: Drake, J.A., Di Castri, F., Groves, R., Kruger, F.J., Mooney, H.A., Rejmánek, M., Williamson, M. (Eds.), Biological Invasions: A Global Perspective. Wiley, Chichester, pp. 215-255.

Mack, R.N., Lonsdale, W.M., 2001. Humans as global dispersers: getting more than we bargained for. Bioscience 51, 95-102.

McDowell, C.R., 1994. Newlands Forest Vegetation Survey. Parks \& Forest Branch Report, Cape Town City Council. University of Cape Town, Cape Town, 14pp.

McIntyre, S., Lavorel, S., 1994. Predicting richness of native, rare, and exotic plants in response to habitat and disturbance variables across a variegated landscape. Conserv. Biol. 8, 521-531.

McKinney, M.L., 2002. Influence of settlement time, human population, park shape and age, visitation and roads on the number of alien plant species in protected areas in the USA. Diversity Distrib. 8, 311-318.

McLachlan, D., Moll, E.J., 1977. A path and recreation report of Table Mountain. Department of Botany, University of Cape Town, pp. 52-62.

McLachlan, S.M., Bazely, D.R., 2003. Outcomes of long-term deciduous forest restoration in southwestern Ontario, Canada. Biol. Conserv. 113, 159-169.

Murcia, C., 1995. Edge effects in fragmented forests: implications for conservation. Trends. Ecol. Evol. 10, 58-62.

Parendes, L.A., Jones, J.A., 2000. Role of light availability and dispersal in exotic plant invasion along roads and streams in the H.J. Andrews experimental forest, Oregon. Conserv. Biol. 14, 64-75.

Pienaar, K., 1984. The South African What flower is that. Struik, Cape Town, 368pp.

Pyšek, P., Richardson, D.M., Rejmanek, M., Webster, G.L., Williamson, M., Kirschner, J., 2004. Alien plants in checklists and floras: towards better communication between taxonomists and ecologists. Taxon 53, 131-143.

Raloff, J., 2003. Cultivating weeds: is your yard a menace to parks and wildlands? Sci. News 163, 15-18.

Reichard, S., Hamilton, C.W., 1997. Predicting invasions of woody plants introduced into North America. Conserv. Biol. 11, 193-203.

Reichard, S.H., White, P., 2001. Horticulture as a pathway of invasive plant introductions in the United States. Bioscience 51, 103-113.
Richardson, D.M., Cambray, J.A., Chapman, R.A., Dean, W.R.J., Griffiths, C.L., Le Maitre, D.C., Newton, D.J., Winstanley, T.J., 2003. Vectors and pathways of biological invasions in South Africa - past, future and present. In: Ruiz, G., Carlton, J. (Eds.), Invasive Species: Vectors and Management Strategies. Island Press, Washington, DC, pp. 292-349.

Richardson, D.M., Gelderblom, C., van Wilgen, B.W., Trinder-Smith, T.H., 1998. Managing biodiversity on the Cape Peninsula, South Africa: a hotspot under pressure. In: Rundel, P.W., Montenegro, G., Jaksic, F.M. (Eds.), Landscape Disturbance and Biodiversity in Mediterranean-Type Ecosystems. Springer, Berlin, pp. 189-204.

Richardson, D.M., van Wilgen, B.W., Higgins, S.I., Trinder-Smith, T.H., Cowling, R.M., McKelly, D.H., 1996. Current and future threats to plant biodiversity on the Cape Peninsula, South Africa. Biodiv. Conserv. 5, 607-647.

Rodgers, J.C., Parker, K.C., 2003. Distribution of alien plant species in relation to human disturbance on the Georgia Sea Islands. Diversity Distrib. 9, 385-398.

Rose, S., 1997. Influence of suburban edges on invasion of Pittosporum undulatum into bushland of northern Sydney, Australia. Aust. J. Ecol. 22, 89-99.

Rose, S., Fairweather, P.G., 1997. Changes in floristic composition of urban bushland invaded by Pittosporum undulatum in Northern Sydney, Australia. Aust. J. Bot. 45, 123-149.

Rouget, M., Richardson, D.M., 2003. Inferring process from pattern in plant invasions: a semimechanistic model incorporating propagule pressure and environmental factors. Am. Nat. 162, 713-724.

Rouget, M., Richardson, D.M., Cowling, R.M., Lloyd, J.W., Lombard, A.T., 2003. Current patterns of habitat transformation and future threats to biodiversity in terrestrial ecosystems of the Cape Floristic Region, South Africa. Biol. Conserv. 112, 63-85.

Saunders, D.A., Hobbs, R.J., Margules, C.R., 1991. Biological consequences of ecosystem fragmentation: a review. Conserv. Biol. 5, 18-32.

Sousa, W.P., 1984. The role of disturbance in natural communities. Ann. Rev. Ecol. Syst. 15, 353-391.

Stirton, C.H., 1978. Plant Invaders: Beautiful But Dangerous. Department of Nature \& Environmental Conservation of the Cape Provincial Administration, Cape Town.

Struglia, R., Winter, P.L., 2002. The role of population projections in environmental management. Environ. Manag. $30,13-23$.

Sullivan, J., Timmins, S., Williams, P., Forester, L., McCluggage, T., 2001. Movement of environmental weeds from coastal settlements into coastal native forests of northern New Zealand, Department of Conservation, Landcare Research, New Zealand Ltd., 30pp.

ter Braak, C.J.F., Smilauer, P., 1998. CANOCO Reference Manual and User's Guide to Canoco for Windows: Software for Canonical Community Ordination Version 4. Microcomputer Power, Ithaca, NY. 352pp.

Thompson, H.C., 1999. Study finds adjacent land uses are key to predicting the number and type of exotic species in forest gaps (Maryland). Ecol. Restor. 17, 159-160.

Timmins, S.M., Williams, P.A., 1991. Weed numbers in New Zealand's forest and scrub reserves. New Zealand J. Ecol. 15, 153-162.

Trinder-Smith, T.H., Cowling, R.M., Linder, H.P., 1996. Profiling a besieged flora: endemic and threatened plants of the Cape Peninsula, South Africa. Biodiv. Conserv. 5, 575-589.

Tyser, R.W., Worley, C.A., 1992. Alien flora in grasslands adjacent to road and trail corridors in Glacier National Park, Montana (USA). Conserv. Biol. 6, 253-262.

Vujnovic, K., Wein, R.W., Dale, M.R.T., 2002. Predicting plant species diversity in response to disturbance magnitude in 
grassland remnants of central Alberta. Can. J. Bot. Rev. 80, 504-511.

Walter, J.N., Fourier, R.A., Soudani, K., Meyer, E., 2003. Integrating clumping effects in forest overstorey structure: an assessment through hemispherical photographs. Can. J. Remote Sens. 29, 388-410.

Wells, M.J., Poynton, R.J., Balsinhas, A.A., Musil, K.J., Joffe, H., van Hoepen, E., Abbott, S.K., 1986. The history of introduction of invasive alien plants to southern Africa. In: Macdonald, I.A.W.,
Kruger, F.J., Ferrar, A.A. (Eds.), The Ecology and Management of Biological Invasions in Southern Africa. Oxford University Press, Cape Town, pp. 21-35.

Yates, E.D., Levia Jr., D.F., Williams, C.L., 2004. Recruitment of three non-native invasive plants into a fragmented forest in southern Illinois. Forest Ecol. Manag. 190, 119-130.

Zavaleta, E.S., Hobbs, R.J., Mooney, H.A., 2001. Viewing invasive species removal in a whole-ecosystem context. Trends Ecol. Evol. 16, 454-459. 